International Journal of Business Management and Economic Review

Vol. 3, No. 01; 2020

ISSN: 2581-4664

\title{
THE INFLUENCE OF INTELLECTUAL CAPITAL ON FIRM VALUE WITH FINANCIAL PERFORMANCE AS INTERVENING VARIABLES IN BANKING COMPANIES LISTED IN INDONESIA STOCK EXCHANGE
}

\author{
M. Shalahuddin, Mohamad Adam and MarlinaWidiyanti \\ Magister Management Sriwijaya University, Indonesia \\ http://doi.org/10.35409/IJBMER.2020.3145
}

\begin{abstract}
This study aims to examine the effect of intellectual capital variables on firm value with financial performance as an intervening variable on banking companies listed on the Indonesia Stock Exchange (IDX). Samples taken as many as 30 companies during the period 2014-2018 based on purposive sampling method. Data processing is used by regression analysis and path analysis. The results showed that: (1) Intellectual Capital which is proxied by Value Added Intellectual Coefficient (VAICTM) does not have a significant effect on Company Value that is proxied by Price-to-book Value (PBV), (2) VAICTM has a significant positive effect on Performance Finance proxied by Earnings Per Share (EPS) and Return on Assets (ROA), (3) EPS has no significant effect on PBV while ROA has a positive effect on PBV, (4) The result is the ROA variable can act as an intervening variable while the EPS variable doesn't.
\end{abstract}

Keyword:Intellectual Capital, Value Added Intellectual Coefficient (VAICTM)",Price-to-book Value (PBV), Earnings Per Share (EPS), Return on Assets (ROA)".

\section{INTRODUCTION}

The business industry has continued to increase since the invention of the steam engine in the 18th century. The development of the business industry continues to increase and business management continues to develop where initially the focus on physical management shifted to non-physical management also needs attention. This development provides many impacts in the application of corporate strategy in competition. Many companies use labor-based business principles. The more employees the higher the productivity so the company grows. Switching from labor-oriented business to knowledge-oriented business with the main characteristics of knowledge must be done by the company to be able to survive today. (Sawarjono and Kadir, 2003). So, in order for a company to survive, it must move from "work based business" to "knowledge based business" with the basic characteristics of science.

The current state of the business environment, turning a business into a knowledge-based business, the company's dominant priority changes from tangible assets to intangible assets. The development of a science-based economy makes companies to increase the so-called intellectual capital. 


\section{International Journal of Business Management and Economic Review}

Vol. 3, No. 01; 2020

ISSN: 2581-4664

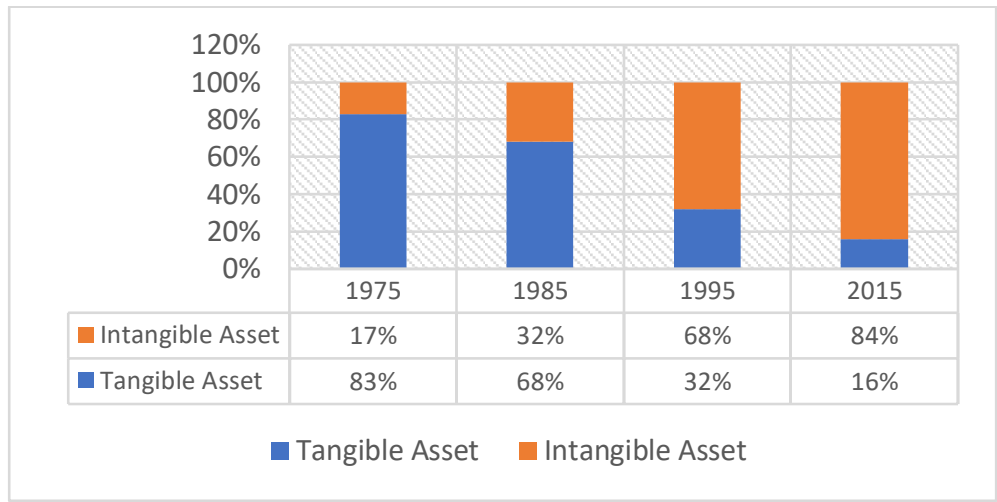

Figure 1. Growth in market value components in S \& P500 companies Source: Website Oceantomo.com

The table above shows the phenomenon of changes in corporate priorities in which initially tangible assets play a major role shifting to intangible assets in creating a company's market value. this also happened to various companies in various parts of the world including Indonesia.Edvinsson (1997) defines intellectual capital as something that is not explicitly recorded in a company's financial statements and is intangible, but has an important role in improving the performance of the financial statements themselves.

Pulic (1998) states the results of intellectual potential and physical capital are the intellectual abilities of the company. According to him intellectual abilitywhich is then referred to as VAICTM, is a reflection of the extent to which companies utilize both resources efficiently. The greater and more efficient use of intellectual capital is believed to have a role that has an impact on increasing company value and financial performance. Companies that can utilize their intellectual capital efficiently then the company's performance can be said to be good with a good financial performance of the company, eventually the company's market value will increase.Knowing the most influential elements in intellectual capital will help companies identify what models are good for the company to help the company's success (Nazari, 2010).

The banking sector is listed on the Indonesian stock exchange is the focus of this study. Firm value is measured by price-to-book value (PBV).

Table 1. Average PBV in banking sector

\begin{tabular}{|ll|}
\hline Year & PBV (mean) \\
\hline 2014 & 1.44 \\
\hline 2015 & 1.29 \\
\hline 2016 & 1.50 \\
\hline 2017 & 1.67 \\
\hline 2018 & 1.52 \\
\hline
\end{tabular}

Source: Indonesia stock exchange (data processed) 


\section{International Journal of Business Management and Economic Review}

Vol. 3, No. 01; 2020

ISSN: 2581-4664

The table above can be seen that the value of companies proxied by PBV in the banking sector is not fixed or fluctuating. However, the table shows that the average PBV in the banking sector is more than 1 , meaning that the average share price in this sector is valued more expensive than the book value. This figure reflects that the average value of companies in the banking sector is quite good.

Other researchers have extensively examined this and differences in the results of the study have been suggested. Former researchers proved the significant positive impact of intellectual capital on firm value is Fitriasari and Ratnasari (2019), Yofita and Amrania (2018)whileNuhuyanan (2016) and found a negative relationship.

Smriti and Das (2018), Sardo and Zelaia (2017), Ranani and Bijani (2014) found that intellectual capital had a positive influence on financial performance. Whereas Ozkan et al (2016) found the opposite results. Based on what has been presented and also the research gap of various studies, the author feels interested in conducting research to see how intellectual capital influences both directly and indirectly.

\section{LITERATURE REVIEW}

\section{a. Resources Based-theory (RBT)}

Resources based theory (RBT) was proposed by Warnerfelt (1984). Resource theory (resource based theory) suggests how companies manage their resources to gain competitive advantage through their intellectual abilities. Productive services available from resources that provide unique characteristics for each firm because the firm's resources are not homogeneous (Yuskar and Novita: 2014).

\section{b. Signalling Theory}

Signal theory indicates that companies continue to provide signals such as positive information (good performance) in the form of financial statements to investors so that they are expected to receive a positive response from the market.

Williams (2001) says companies continue to try to give positive signals to potential investors through disclosure of financial statement information. It is expected to increase investor confidence so as to give a good impression to the company and provide benefits to the company.

Al-Ghifari, et al (2013) argues that financial performance can be a signal of information for investors about future cash flows. According to Miller (1999) managing intellectual capital provides the potential to increase funding or investment because intellectual capital can be a positive signal for investors.

\section{c. Intellectual Capital}

Different definitions of intellectual capital have been described by experts. Many experts say that intellectual capital has a very large role in adding value to an activity including company independence.

Companies to achieve competitive advantage must at least treat physical capital and financial capital the same as intangible capital so that all company resources can be optimized (Yuskar and Novita: 2014).

\section{d. Value Added Intellectual Coefficient(VAICTM)}

Ante Pulic (1998) developed the VAICTM model based on the Scandina Navigator 
Vol. 3, No. 01; 2020

ISSN: 2581-4664

model, this model presents information about the efficiency of value creation.. VAIC measures the level of efficiency of tangible and intangible asset resources used by companies. VAIC starts by calculating the value added obtained through the difference among output (OUT) and input (IN) (Pulic, 1998). Pulic (2008) argues that only creating value added is not enough but that the company must also be efficient in managing its capital.

\section{e. Relationship and Influence Between Variables}

Companies that manage capital well and efficiently can be said that the company will get good value from the market. Belkaoui (2003) argues that companies investing their intellectual capital can be seen from the difference in market value and book value presented in the company's financial statements.. So, if for example the market is efficient, then investors will give high value to companies that have bigger IC. This fits in with RBT (resource-based theory) where an increase in intellectual capital will have a positive impact on value creation in the company.

According to Kasmir (2016) to obtain the intended profits, the main key is the support of all human resources owned because human resources are the driving force of all company activities.Intellectual capital will positively influence the company's financial performance. Companies that manage their capital well will increase profits so they will be considered good by the market.

Based on what has been presented previously shows that intellectual capital can have a positive effect on company value and financial performance. Financial performance has a positive effect on firm value based on the theory of signaling. In this era where business is based on knowledge of intellectual capital will be very needed to increase the value and performance of the company. Companies that are committed in forming good capital will improve the financial performance of the company and eventually investors will be interested in investing in the company.

\section{Framework}

Based on the theory that has been explained before, the framework of this research can be made as follows:

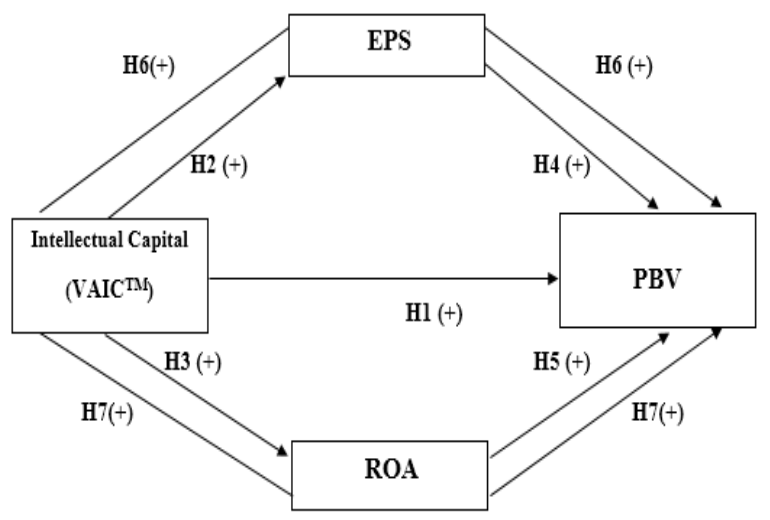

Figure 2 Framework Model 
International Journal of Business Management and Economic Review

Vol. 3, No. 01; 2020

ISSN: 2581-4664

\section{Hypothesis}

The hypothesis proposed is based on the above proposed up to H1-H7. Everything that is hypothesized has a direct or indirect positive effect.

\section{RESEARCH METHODS}

\section{a. Data Types and Sources}

The data used in this research is secondary data. Secondary data is a source of data collected indirectly from various sources that already exist as intermediary media. The data is taken from the idx.co.id website

\section{b. Population and Sample}

All banking companies listed on IDX (Indonesia Stock Exchange) are the study population. the research period from 2014 to 2018 and samples taken were 30 companies.

\section{c. Variable Definition}

Intellectual capital variables will be measured using the Pulic method in this study. Intellectual capital is calculated based on value added created by physical capital / employed capital (VACA), human capital (VAHU), and structural capital (STVA). This combination of three is called VAICTM developed by Pulic (1999). The VAICTM calculation steps based on the Pulic model are as follows:

1. Calculating added value (VA). Calculating VA $=$ OUT-IN. OUT $=$ total net sales and other income, $\mathrm{IN}=$ expenses (other than salary). VA can also be calculated $\mathrm{VA}=\mathrm{P}+\mathrm{C}+\mathrm{D}+\mathrm{A} . \mathrm{P}=$ operating profit; $\mathrm{C}=$ labor costs; $\mathrm{D}=$ depreciation; $\mathrm{A}=$ amortization.

2. Calculating the VACA value. VACA shows the contribution generated by each capital invested in the company. VACA $=\mathrm{VA} /$ equity.

3. Calculating VAHU which VAHU is a major contribution made by VA invested into human resources (HR). VAHU is calculated by dividing VA against labor costs.

4. Calculating STVA. This ratio calculates the number of SC needed to produce 1 Dollar from VA. STVA = SC / VA.

5. The final stage is the calculation of VAICTM. VAICTM = VACA + VAHU + STVA.

The company's value in this study was calculated using price-to-book value (PBV). PBV is calculated by dividing stock prices by the book value of shares (Brigham and Houston, 2014). Financial performance in this study used earnings per share (EPS) and return on assets (ROA).

\section{d. Data analysis technique \\ Descriptive Analysis}

This analysis consists of the mean or average value of each variable which illustrates the average value in the banking sector. In addition to the mean or average descriptive analysis also includes standard deviation, maximum, minimum that will be presented in this study.

\section{Path Analysis}

Path analysis is one of the types of regression analysis which is one of the statistical test techniques. The path diagram explicitly provides causality relationships between variables with each other based on theory. Each relationship between variables is shown through arrows and each value $\beta$ describes the magnitude of the value of the path coefficient (Pardede and Manurung, 2014). Basically, the path coefficient is a standardized regression weights or compares the coefficient of indirect effect with the coefficient of direct effect. 
The path analysis regression equation in this study is:

$\mathrm{EPS}=\beta 1 \mathrm{VAICTM}+\mathrm{e} 1 \ldots . . .($ Equation 1$)$

$\mathrm{ROA}=\beta 2 \mathrm{VAICTM}+\mathrm{e} 2 \ldots . . .($ Equation 2$)$

$\mathrm{PBV}=\beta 3 \mathrm{VAICTM}+\beta 4 \mathrm{EPS}+\beta 5 \mathrm{ROA}+\mathrm{e} 3$ (Equation 3)

\section{TEST RESULTS}

\section{a. The results of descriptive statistics}

Table 2. Descriptive Statistics

\begin{tabular}{|l|r|r|r|r|r|}
\hline & $\mathrm{N}$ & Minimum & Maximum & Mean & Std. Deviation \\
\hline VAIC $^{\text {TM }}$ & 150 & 1,181 & 5,011 & 2,92005 & 0,829773 \\
\hline EPS & 150 & 1,54 & 1049 & 151,0699 & 237,09175 \\
\hline ROA & 150 & 0,13 & 4,73 & 1,75840 & 1,07144 \\
\hline PBV & 150 & 0,210 & 4,2 & 1,48137 & 0,889597 \\
\hline
\end{tabular}

Source: data processed(SPSS output)

Based on the results above the VAICTM variable is centralized or generally located close to the value of 2.92. The average value is greater than the std. deviation value of 2.92>0.829773, which means that the VAICTM data distribution is good. The average EPS value is 151.0699 and the std .deviation is 237.09175. EPS variable average value is smaller than the std deviation that is $151.0699<237.09175$, which means the distribution of EPS data is not good. ROA values are more centralized and are generally located at 1.7584 . The average value of ROA is greater than the std deviation of 1.7584> 1.07144, which means ROA has good data distribution. The average PBV value is 1.48137 which means that the PBV value is centered and is generally located close to that value. The average value is greater than the std. deviation that is 1.48137> 0.889597 which means that the distribution of PBV values is good.

\section{b. Coefficient of Determination}

Table 3. Coefficient of Determination in Equation 1

\begin{tabular}{|c|c|c|c|}
\hline $\begin{array}{c}\text { Equation 1 } \\
\text { Model }\end{array}$ & $R$ & R Square & $\begin{array}{c}\text { Adjusted } R \\
\text { Square }\end{array}$ \\
\hline Effect of VAICTM on EPS & 0,795 & 0,633 & 0,630 \\
\hline
\end{tabular}

Source; data processed

Table 4. Coefficient of Determination in Equation 2

\begin{tabular}{|c|c|c|c|}
\hline $\begin{array}{c}\text { Equation 2 } \\
\text { Model }\end{array}$ & $\mathrm{R}$ & R Square & $\begin{array}{c}\text { Adjusted R } \\
\text { Square }\end{array}$ \\
\hline Effect of VAICTM on ROA & 0,883 & 0,779 & 0,778 \\
\hline
\end{tabular}

Source: data processed 


\section{International Journal of Business Management and Economic Review}

Vol. 3, No. 01; 2020

ISSN: 2581-4664

\begin{tabular}{|l|l|c|c|c|}
\hline \hline \multicolumn{4}{|c|}{ Table 5. Coefficient of Determination in Equation 3 } \\
\hline \begin{tabular}{|l|c|c|c|}
\hline $\begin{array}{c}\text { Equation 3 } \\
\text { Model }\end{array}$ & $R$ & R Square & $\begin{array}{c}\text { Adjusted R } \\
\text { Square }\end{array}$ \\
\hline $\begin{array}{l}\text { Effect of VAICTM, EPS and } \\
\text { ROA on PBV }\end{array}$ & 0,407 & 0,166 & 0,148 \\
\hline
\end{tabular}
\end{tabular}

Source; data processed

Table 3 is the result of equation 1 showing the coefficient of determination or adjusted $\mathrm{R}$ square with a value of 0.630 or $63 \%$. Figures show the contribution of the independent variable, VAICTM, to EPS. VAICTM is able to explain the EPS variable of $63 \%$ while the remaining $37 \%$ is explained by other variables or factors.

Table 4 shows the value of VAICTM's contribution to ROA with an adjusted $\mathrm{R}$ square value of 0.778 . VAICTM shows or can explain the $77.8 \%$ ROA variable while the remaining $22.2 \%$ is described by other variables. Table 5 shows the coefficient of determination of VAICTM, EPS and ROA for PBV from the output results shows the adjusted R square value of 0.148. The VAICTM, EPS and ROA variables are only able to explain $14.8 \%$ of the PBV variable while the rest are factors beyond that.

\section{c. F Test}

The F test was used to test the effect of the VAICTM variable along with EPS and ROA on the PBV variable. The criteria used is the existence of a significant influence if the value of Sig.F> 5\% (0.05). Below is a table with the results of the F test:

Tabel 6. Output Anova

\begin{tabular}{|c|c|c|c|c|c|c|}
\hline \multicolumn{7}{|c|}{ ANOXA: } \\
\hline Moc & & Sum of Squares & $\mathrm{df}$ & Mean Square & $\mathrm{F}$ & Sig. \\
\hline \multirow[t]{3}{*}{1} & Regression & 10.106 & 3 & 3.369 & 9.660 & $.000^{\circ}$ \\
\hline & Residual & 50.912 & 146 & 349 & & \\
\hline & Total & 61.017 & 149 & & & \\
\hline
\end{tabular}

Source : data processed

The table above shows the Fcount value of 9,660 is greater than the Ftable value of only 2,670. The table signification shows a value of 0,000 or less than 0.05 ( $\mathrm{sig}$. <0.05). so, based on the results obtained it was concluded that VAICTM, EPS and ROA together influence PBV.

\section{d. Significance Test Results for Individual Parameters (t test) Individual Parameter Signification Test Results (t test) in Equation 1}


International Journal of Business Management and Economic Review

Vol. 3, No. 01; 2020

ISSN: 2581-4664

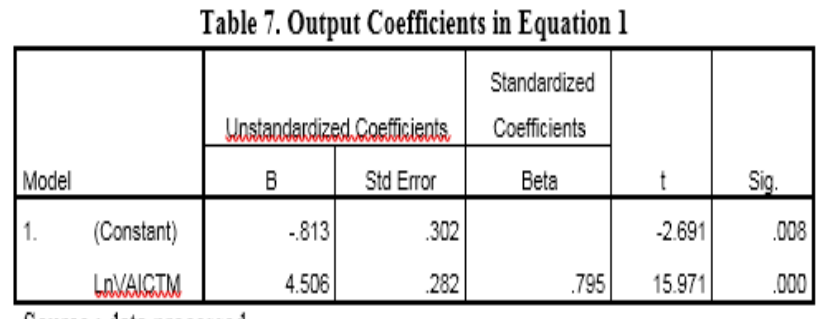

Source : data processed

Table 7 above shows the value of the effect of VAICTM on EPS has a significance value of $0.000<5 \%$ or 0.05 . Tcount $>$ ttable is $15.971>1.976$. Based on the above results it can be decided that intellectual capital (VAICTM) has a significant positive effect on EPS and H2 is accepted. The path equation formula that can be made from the table above is as follows:

YEPS = 0,795 VAIC $^{\text {TM }}+$ e

From the above equation it can be seen that the path coefficient that we use for path analysis is standardized coefficients that is equal to 0.795 .

\section{Significance Test Results for Individual Parameters (t test) in Equation 2}

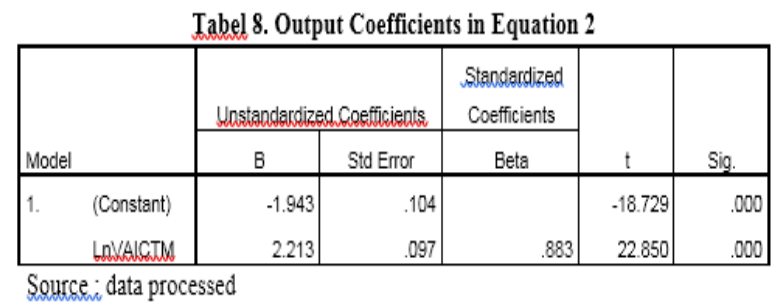

Table 8 above shows the value of the effect of VAICTM on ROA which based on table 8 , the value of tcount $>$ ttable is $22.850>1.976$ and the significance value is less than $5 \%$ (sig. $<0.05$ ). So, it can be concluded that intellectual capital (VAICTM) has a significant influence on ROA and $\mathrm{H} 3$ is accepted.

Based on table 8, we can make the equation for the path as below:

YROA $=0,883 \mathrm{VAIC}^{\mathrm{TM}}+\mathrm{e}$

The value of 0.883 is the path coefficient that will be used in the path analysis.

Significance Test Results for Individual Parameters (t test) in Equation 3

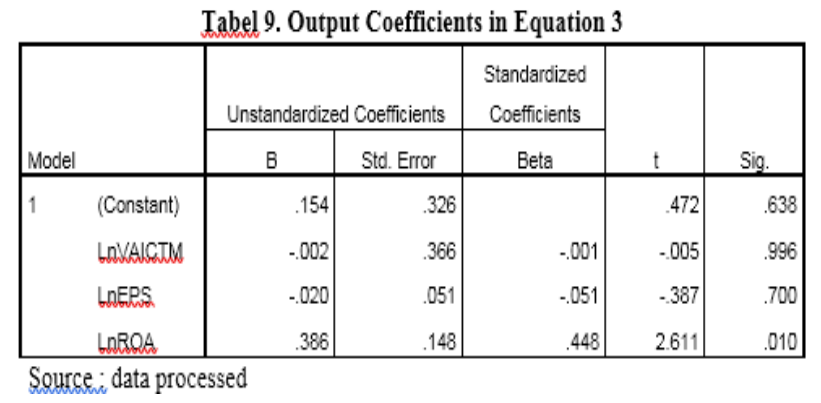

Based on the table above which has an influence where the value of Sig <0.05 (5\%) only ROA which means H5 is accepted. Meanwhile, H1 and H4 were rejected because VAICTM and EPS 
International Journal of Business Management and Economic Review

Vol. 3, No. 01; 2020

ISSN: 2581-4664

had no influence on PBV.

\section{e. Path Analysis Results}

Based on table 7 shows the regression test of VAICTM's direct effect on PBV, from which it can be seen that the standardized coefficients of VAICTM's direct effect on PBV are 0,001 . Table 9 shows that VAICTM and EPS do not have a direct relationship or influence on firm value (PBV). Table 7 is the output that shows the direct effect of VAICTM on EPS.

The explanation above shows that in fact we can conclude that EPS in this case was hypothesized as an intervening variable which was not proven. The requirement to say there is an indirect relationship or influence is if the influence of the independent variable on intervening and intervening variables also have an influence on the dependent variable.

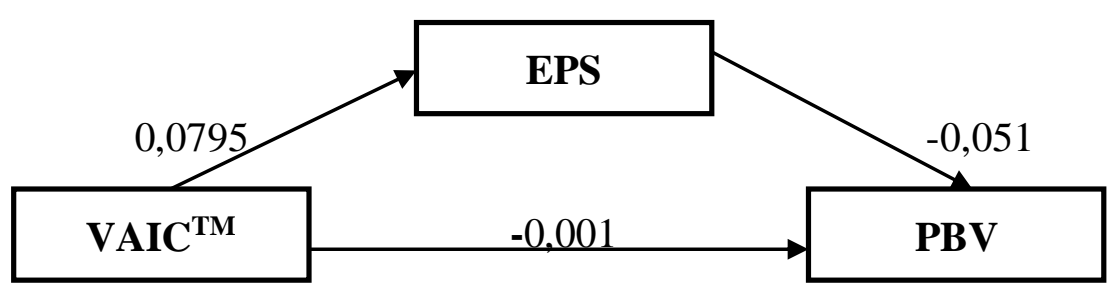

Figure 3. Path Analysis Results Through EPS

Source: data processed(SPSS output)

The results showed that VAICTM did not have a direct relationship with PBV and also did not have an indirect relationship with PBV via EPS.

Table 9 shows the results of the direct effect of VAICTM, EPS and ROA on PBV. The path coefficient of ROA influence on PBV can be seen from the standardized coefficients of 0.448. The path coefficient of VAICTM influence on ROA can be seen in Table 9 the standardized coefficient value is 0.883 .

Indirect effects can be known by comparing the direct and indirect effects of variables. The indirect effect of VAICTM on PBV through ROA can be determined by multiplying the standardized coefficients of VAICTM on ROA and the value of standardized coefficients of ROA on PBV. The calculation results obtained indirect effect of VAICTM on PBV through ROA is $0.883 \times 0.448=0.395$. The results of the calculation analysis are shown below:

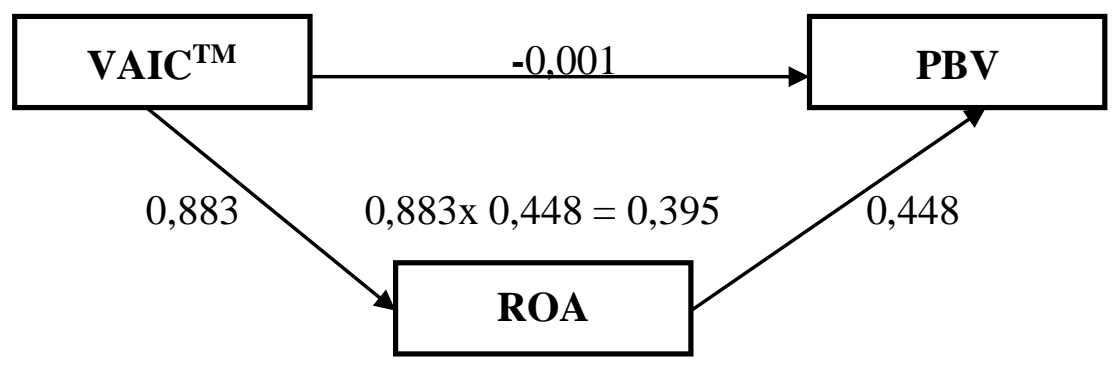




\section{International Journal of Business Management and Economic Review}

Vol. 3, No. 01; 2020

ISSN: 2581-4664

\section{Figure4. Path Analysis Results Through ROA \\ Source :data processed(SPSS output)}

Based on the results above the standardized coefficients value of the indirect effect of VAICTM on firm value (PBV) that is equal to 0.395 greater than the value of standardized coefficients of the direct effect of VAICTM on firm value (PBV) -0.001. So it can be concluded that although VAICTM does not directly have an influence but indirectly ROA can play an intervening role on the effect of VAICTM on firm value (PBV).

\section{DISCUSSION}

Based from the results of the statistical output analysis that has been done on hypothesis 1. The results show that intellectual capital(VAICTM) has no impact on firm value (PBV). The Significance value of VAICTM on PBV shows results greater than 5\%, 0.996>0.05. Based on this it can be decided that intellectual capital "does not have a significant effect" on firm value.

The results are different from what has been hypothesized by this study. The resultssof this study are the same or match with research from Yilmaz and Acar (2018), Susy Suhendra (2016)their research also shows that intellectual capital has no significant effect on firm value. These results indicate that intellectual capital may not be too focused on banking companies in Indonesia or most banking companies do not apply modern management concepts too much. The results that show no influence show that the company allocates more funds to human resources (HR) and other resources.

The calculation results show the positive influence of VAICTM on EPS and ROA. The significance value of VAICTM influence on EPS and ROA is $5 \%$ smaller, $0,000<0.05$. So, based on the results of Hypothesis $2(\mathrm{H} 2)$ and Hypothesis $3(\mathrm{H} 3)$ are accepted. These results are the same as research conducted by Fitriasari and Ratna Sari (2019), Ginesti et al (2018), Smriti and Das (2018), Sardo and Zelaia (2017), Venogopal and Subha MV (2015), Ranani and Bijani (2014). These results are the same as RBT theory where the management of physical and nonphysical assets effectively and efficiently is a superior company characteristic. In this case the company in the banking sector manages its assets efficiently so that from efficient management will minimize costs and return ratios will increase.

The results are different from what was hypothesized in hypothesis 4 after looking at the output of statistical tools. The significance value ofEPS to PBV shows a value of more than 5\%, that is $0.700>0.05$. These results are then we can conclude that there is "no significant effect" of EPS on PBV and hypothesis 4 is rejected. The results ofthis study are the same as the research conducted by Susy Suhendra (2015), the results of the study indicate that EPS does not have a significant effect on firm value. It is possible that investors in choosing investments not only see EPS or not only consider the company's financial ratios but also consider other things as well. This also indicates that the large EPS value does not always make the company value also high.

Tests that have been done show that return on assets (ROA) has a "positive effect" on PBV. This result is based on the calculation output that has been seen the ROA significance value of PBV shows a value below 5\%, that is $0.010<0.05$ then $\mathrm{H} 5$ is accepted. These results indicate an increase in ROA means that the firm's return increases indicating the firm has good performance and the impact of the firm's value will rise.

Through EPS, the path test results show that H6 is rejected. Whereas through ROA, ROA 


\section{International Journal of Business Management and Economic Review}

Vol. 3, No. 01; 2020

ISSN: 2581-4664

is able to mediate the indirect relationship of intellectual capital to firm value. This is shown from the results of the path analysis research that has been shown previously where the value of the path coefficient or standardized coefficients of the indirect effect of VAICTM on PBV is greater than the value of the standardized coefficients of the direct effect of VAICTM on firm value(PBV). The value of the path coefficient of indirect influence through ROA obtained by 0.395 is greater than the value of direct influence which is only -0.001 .

These results are the same as research conducted by Fitriasari and Ratna Sari (2019), Mirwan (2018), Yofita and Amrania (2018), Nuhuyanan (2016), Susy Suhendra (2015). This also matches with RBT theory and signaling theory where RBT theory states the company's excellence can be achieved through the company's intellectual ability and the signal theory states the company's superiority or good performance will give a signal to the external company so as to rise the value of the firm.

\section{CONCLUSION}

1. VAICTM has no effect on PBV.

2. VAICTMhas a positive effect on EPS and ROA

3. EPS has no effect on PBV and failed as a mediating variable.

4. ROA has a positive effect on PBV and can mediate the effect of VAICTM on PBV.

\section{REFERENCES}

Alghifari, E. S., Triharjono, S., \&Juhaeni, Y. S.2013. Effect of Return on Assets ( ROA ) Against Tobin' s Q: Studies in Food and Beverage Company in Indonesia Stock Exchange Years 2007-2011. International Journal of Science and Research (IJSR), India Online. Vol. 2(1), 2011-2014.

Belkaoui, A. R. 2003. Intellectual Capital and Firm Performance of US. Multinational Firms: a Study of The Resource-Based and Stakeholder.

Brigham, E. F., dan Houston, J. F. 2010. Dasar-dasarManajemenKeuangan (Essentials of Financial Management), Buku 1 Edisi 11 (Alih Bahasa: Ali Akbar Yulianto).Jakarta: SalembaEmpat.

Edvinsson L, Malone M. 1997. Intellectual Capital: Realizing Your Company's True Value by Funding Its Hidden Brainpower. Harper Business: New York, NY.

Fitriasari\&Ratna Sari, M.N. 2019. "Pengaruh Intellectual Capital Pada Nilai Perusahaan denganKinerjaKeuanganSebagaiVariabel JurnalAkuntansiUniversitasUdayana, Vol 26 No.3.

Intervening".

E-

Ginesti, G., A. Caldarelli, dan A. Zampella. 2018. Exploring the impact of intellectual capital on company reputation and performance. Journal of Intellectual Capital, Vol. 19, No. 5, hlm: 915-34.

Guthrie, J., dan R. Petty. 2000. Intellectual Capital: Australian Annual Reporting Practices. Journal of Intellectual Capital, Vol. 1, No. 3, hlm 241-251.

Jamal Aldin Nazari, 2010, An Investigation of the Relationship between the Intellectual Capital Components and Firm's Financial Performance, Library and Archives Canada.

Kasmir. 2012. AnalisisLaporanKeuangan, Jakarta: PT. Raja GrafindoPersada.

Kasmir. 2016. ManajemenSumberDayaManusia (Teori dan Praktik), Jakarta: PT. Raja 
Vol. 3, No. 01; 2020

ISSN: 2581-4664

\section{GrafindoPersada.}

Nuhuyanan, et al. 2016. "Efeect of Intellectual Capital of the Company with Market Value of Financial Performance as an Intervening Variable. Imperial Journal of Interdisciplinary Research. Vol. 2, Issue 6.

Ocean Tomo. Intangible asset market value. 2015. Diambil pada tanggal 20 Juni 2019 dari https://www.oceantomo.com/intangible-asset-market-value-study/.

Ozkan, Nasif., Sinan Cakan, dan Murad Kayacan. 2016. Intellectual Capital and Financial Performance: A study of the Turkish Banking Sector. Borsa Istanbul Review. Vol. 17 Issue. 3 pp. 190-198. DOI:https://doi.org/10.1016/j.bir.2016.03.001.

Pulic, A. 1998. Measuring the Performance of Intellectual Potential in Knowledge Economy, Paper presented at the 2nd McMaster World Congress on Measuring and Managing Intellectual Capital by the Austrian Team for Intellectual Potential.

Pulic, A. 2000. VAICTM_an accounting tool for IC management. International Journal of Technology Management, 20(5/6/7/8), 702-714.

Ranani, H. S., \&Bijani, Z. 2014. The Impact of Intellectual Capital on the Financial Performance of Listed Companies in Tehran Stock Exchange. International Journal of Academic Research in Accounting, Finance and Management Science, Vol. 4 No.1, pp. 119-127.

Sardo, F., dan Z. Serrasqueiro. 2017. A European empirical study of the relationship between firms' intellectual capital, financial performance and market value. Journal of Intellectual Capital, Vol. 18, No. 4, pp. 771-88.

Sawarjuwono, T. Kadir, P.A. 2003. Intellectual Capital: Perlakuan, Pengukuran, dan Pelaporan (Sebuah Library Research). JurnalAkuntansi dan Keuangan. Vol. 5 No. 1. pp. 35-57.

Smriti, N., dan N. Das. 2018. The impact of Intellectual Capital on Firm Performance: a study of Indian firms listed in COSPI. Vol. 19.

Suhendra, Euphrasia Susy. 2015. The Influence of Intellectual Capital on Firm Value towards Manufacturing Performance in Indonesia. International Coference on Eurasian Economies.

Williams. 2001. Intellectual Capital Performance and Disclosure Practised Related. Journal of Intellectual Capital, 192-203.

Venugopal, D. \&Subha. M.V. 2015. Impact if Intellectual Capital on Corporate Performance : Managing Intellectual Capital and Innovation for Sustainable and Inclusive Society: Managing Intellectual Capital and society. Make Learn and TIIM Joint International Confrerence 2. pp.675-687. Bary, Italy: Toknow press.

Yuskar dan Dhia Novita. 2014. AnalisisPengaruh Intellectual Capital terhadap Nilai Perusahaan denganKinerjaKeuangansebagaiVariabel Intervening pada Perusahaan Perbankan di Indonesia. JurnalManajemen dan BisnisSriwijaya Vol.12 No.4. 